\title{
Numerical Study on the Thermal Performance of Trombe Wall for Passive Solar Building in Semiarid Climate
}

\author{
Maher Dhahri $\left(\mathbb{D},{ }^{1,2}\right.$ Nima Khalilpoor $\left(\mathbb{D},{ }^{3}\right.$ Hana Aouinet, ${ }^{4}$ Alibek Issakhov ${ }^{(D)}{ }^{5}$ \\ Habib Sammouda, ${ }^{2}$ and Sampath Emani ${ }^{6}$ \\ ${ }^{1}$ Higher Institute of Agricultural Sciences of Chott Mariem, University of Sousse, BP No. 47, 4042 Sousse, Tunisia \\ ${ }^{2}$ Laboratory of Energy and Materials (LabEM) (LR11ES34), High School of Sciences and Technology of Hammam Sousse, \\ Sousse University, BP, 4011 Hammam Sousse, Tunisia \\ ${ }^{3}$ Department of Energy Engineering, Graduate School of the Environment and Energy, Science and Research Branch, \\ Islamic Azad University, Tehran, Iran \\ ${ }^{4}$ Higher Private School of Engineering and Applied Techniques (IHE-ESPITA), Sousse, Tunisia \\ ${ }^{5}$ Faculty of Mechanics and Mathematics, Department of Mathematical and Computer Modelling, Al-Farabi Kazakh \\ National University, Almaty, Kazakhstan \\ ${ }^{6}$ Chemical Engineering Department, Universiti Teknologi PETRONAS, Bandar Seri Iskandar, Perak D.R., Malaysia
}

Correspondence should be addressed to Nima Khalilpoor; nimakhalilpoor@gmail.com

Received 2 November 2020; Revised 12 January 2021; Accepted 8 February 2021; Published 1 March 2021

Academic Editor: Hafiz Muhammad Ali

Copyright ( 2021 Maher Dhahri et al. This is an open access article distributed under the Creative Commons Attribution License, which permits unrestricted use, distribution, and reproduction in any medium, provided the original work is properly cited.

The largest amount of energy in buildings is consumed to provide heating, cooling, and ventilation. Therefore, a practical solution such as using renewable energy sources can be considered to reduce energy costs and pollutants. In addition, architecture principles must be varied to utilize passive solar energy and also to reduce energy losses. In this research, a numerical study is presented to investigate the thermal behavior of TW-FR (Trombe wall placed in a fenestrated room) in the semiarid region of Tunisia. Computational fluid dynamic (CFD) simulation of fluid flow and heat transfer shows good agreement with published data in literature. The thermal comfort level was calculated according to ASHRAE (55-2013). The results show that (i) the normal Trombe wall cannot assure a satisfactory comfort level even in summer conditions and a higher vertical temperature gradient can take a value of $15^{\circ} \mathrm{C}$, and the Trombe wall is shown to be more efficient in heating mode in the studied semi-arid region compared to cooling; (ii) the operative temperature for the coldest winter is between 17.85 and $19.85^{\circ} \mathrm{C}$. The air temperature gradient in the comfort ranges between the head and feet is $2.3^{\circ} \mathrm{C}$; and (iii) the Trombe wall is an excellent solution for Sousse city weather; it is suggested that the passive system (TW-FR) will be examined for a whole year to have a precise evaluation of its efficiency.

\section{Introduction}

The applications of renewable energies have fascinated the interest of many architects and engineers in recent days [1, 2]. Several researches have shown the potential of using solar energy for satisfying energy demands of buildings [3-5] and industries [6] to alleviate the pollutant emission crisis $[7,8]$.

A thermal mass storage that comprised of external glazing, dampers, and vent in order to provide required heating, cooling, and ventilation passively is so-called Trombe wall [9]. In winters, air enters into the cavity through a low vent. The temperature of the air is raised in the wall and transferred to the room through the cavity due to buoyancy effect. In summers, the Trombe wall is performing similar to solar chimney since the low glazing vent will be closed and the high vent is opened [10].

A set of instructions are provided for the Trombe wall design based on experimental and numerical investigations. 
In the first look, the Trombe wall is a promising approach to save energy and to maintain the indoor air quality. Experimental study of room equipped with Trombe wall is offered by [11] where they studied house natural ventilation in arid climate of Yazd, Iran, experimentally by studying different types of fins, namely, brass, copper, and aluminum. The results approved that using thermal fins enhanced the energy-saving efficiency of the Trombe wall by $3 \%$ and improved its natural convection heat transfer rate by $6 \%$ inside the channel.

Dong et al. presented a new configuration for the Trombe wall by installing an absorbent plate between the glass cover and the thermal storage wall and examined it in Harbin, China [12]. It was shown that this novel layout increased the thermal efficiency by $50 \%$ compared to traditional Trombe wall. Abbassi and Dehmani introduced internal thermal fins into a Trombe wall [13]. Wu et al. proposed a 2-dimensional model on air filtration and thermal performance of a PC-Trombe wall [14]. The authors reported that increasing the solar radiation had positive effect on the thermal efficiency and ambient temperature. On the other hand, the air inlet temperature and ambient wind velocity was decreased. Recently, Abdeen et al. carried out an investigation on the heat transfer and air flow of a Trombe wall under quasistate situation in a moderate typical winter week in Alexandria, Egypt [15].

Computational fluid dynamics (CFD) is a viable solution to evaluate the flow behavior and thermal conditions of different systems [16]. In buildings, CFD can be extensively used to analyze energy consumption and to model the system with respect to real values. Risberg et al. simulated the heat supply through ventilation ducts placed at the ceiling in Swedish houses with passive house standards [17].

Bajc et al. presented a 3D CFD modeling and analyzed temperature distribution in the Trombe wall and in the adjacent room in a moderate climate [18]. The authors optimized the Trombe applying various types of glassing on the outer side of the wall and reported that the Trombe wall could be a practical solution for use in Belgrade region.

Overall, it can be understood from the previously discussed publications that the Trombe wall has promising potential to be used in buildings in order to maintain desirable heating and cooling rates. Monitoring the preceding studies showed that there is no comprehensive study on evaluation of thermal comfort in a building where the Trombe wall was installed in semiarid climate.

The application of the Trombe wall in Tunisia is still uncommon due to the lack of information about energy performance and construction details that do not persuade the stake holders to implement this system. This research has this target to display the effect of the space air flow pattern of Trombe wall installed in a fenestrated room.

\section{Numerical Analysis}

2.1. Mathematical Model. The simulations are implemented in ANSYS CFX (15.0). The continuity (Equation (1)), momentum (Equation (2)), and energy (Equation (3)) equations applied to the model are as follows [19]:

$$
\begin{gathered}
\frac{\partial \rho}{\partial t}+\frac{\partial}{\partial x_{i}}\left(\rho u_{j}\right)=0 \\
\rho \frac{\partial u}{\partial t}+\rho(u . \nabla) u=\nabla\left[-p l+\left(\mu+\mu_{\mathrm{T}}\right)\left(\nabla u+(\nabla u)^{T}\right)\right. \\
\left.-\frac{2}{3}\left(\left(\mu+\mu_{\mathrm{T}}\right)(\nabla \cdot u) l-\frac{2}{3} \rho k l\right)\right]+F \\
\frac{\partial \rho}{\partial t}\left(\rho C_{\mathrm{a}} T\right)+\frac{\partial}{\partial x_{j}}\left(\rho u_{j} C_{\mathrm{a}} T\right)-\frac{\partial}{\partial x_{j}}\left(k \frac{\partial T}{\partial x_{j}}\right)=S_{\mathrm{T}}
\end{gathered}
$$

where $C_{\mathrm{a}}$ indicates the water specific heat, $k$ shows the thermal conductivity, $\mu$ is the dynamic viscosity, and $\rho$ denotes density.

The turbulence kinetic energy $(k)$ and its dissipation rate ( $\varepsilon$ ) can be calculated as follows [20]:

$$
\begin{aligned}
\frac{\partial}{\partial t}(\rho k)+\frac{\partial}{\partial x_{i}}\left(\rho k U_{i}\right)= & \frac{\partial}{\partial x_{j}}\left[\left(\mu+\frac{\mu_{t}}{\sigma_{k}}\right) \frac{\partial k}{\partial x_{j}}\right]+G_{k}+G_{\mathrm{b}} \\
& -\rho \varepsilon-Y_{\mathrm{M}}+S_{k} \\
\frac{\partial}{\partial t}(\rho \varepsilon)+\frac{\partial}{\partial x_{i}}\left(\rho \varepsilon U_{i}\right)= & \frac{\partial}{\partial x_{j}}\left[\left(\mu+\frac{\mu_{\mathrm{t}}}{\sigma_{3}}\right) \frac{\partial \varepsilon}{\partial x_{j}}\right] \\
+ & C_{1 \varepsilon} \frac{\varepsilon}{k}\left(G_{k}+C_{3 \varepsilon} G_{\mathrm{b}}\right)-C_{2 \varepsilon} \rho \frac{\varepsilon^{2}}{k}+S_{\varepsilon}
\end{aligned}
$$

where $G_{k}$ indicates the turbulence kinetic energy associated with gradients of the mean velocity and $G_{\mathrm{b}}$ refers to the turbulence kinetic with regard to buoyancy. $Y_{\mathrm{M}}$ is the fluctuating dilatation, $\sigma_{k}$ and $\sigma_{\varepsilon}$ are the Prandtl numbers, and $C_{1 \varepsilon}$, $C_{2 \varepsilon}$, and $C_{3 \varepsilon}$ are constants.

Compared to other turbulence models, the $k-\varepsilon$ model is less nonlinear and has simple convergence that makes it simple to provide a suitable initial guess.

The turbulent viscosity, $v_{\mathrm{t}}$, is obtained as

$$
v_{\mathrm{t}}=C_{\mu} \frac{k^{2}}{\varepsilon},
$$

where $\mathrm{C}_{\mu}$ is a constant.

The values of $\mathrm{C}_{1 \varepsilon}, \mathrm{C}_{2 \varepsilon}, \mathrm{C}_{\mu}, \sigma_{k}$, and $\sigma_{\varepsilon}$ are

$$
\begin{aligned}
C_{1 \varepsilon} & =1.44, \\
C_{2 \varepsilon} & =1.92, \\
C_{\mu} & =0.09, \\
\sigma_{k} & =1.0, \\
\sigma_{\varepsilon} & =1.3,
\end{aligned}
$$




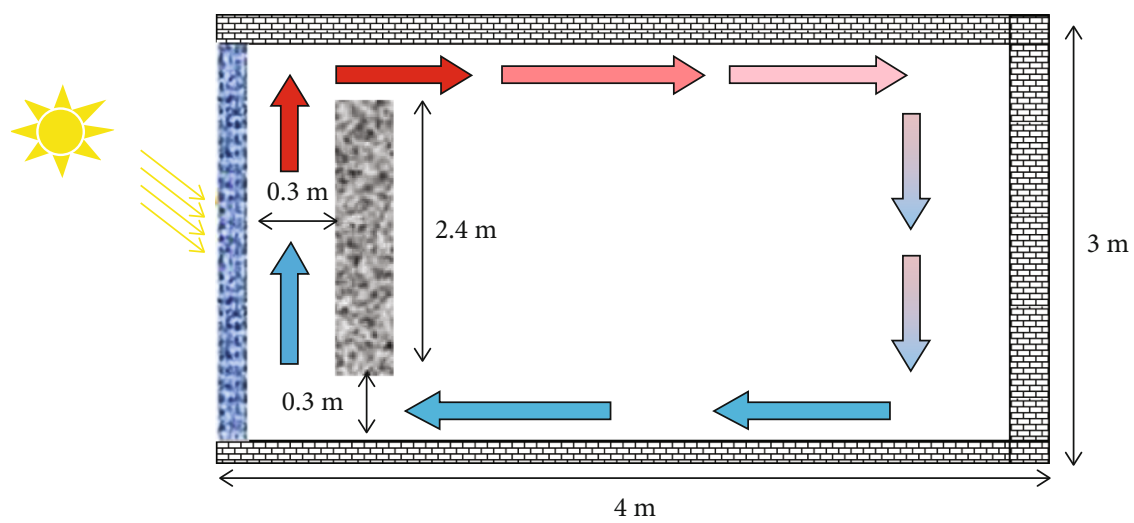

Figure 1: Physical model of the Trombe wall system.

TABLE 1: Summary of the boundary conditions.

\begin{tabular}{lccc}
\hline Element & $T\left({ }^{\circ} \mathrm{C}\right)$ & Type of radiation & $\begin{array}{c}\text { Heat flux }\left(\mathrm{W} / \mathrm{m}^{2}\right) \\
\text { Heat flux coefficient }\left(\mathrm{W} / \mathrm{m}^{2} \mathrm{~K}\right)\end{array}$ \\
\hline Floor & $30^{\circ} \mathrm{C}$ & Not transparent & - \\
Roof & $45^{\circ} \mathrm{C}$ & Not transparent & $250\left(\mathrm{w} / \mathrm{m}^{2} \mathrm{k}\right)$ \\
Glazing & $45^{\circ} \mathrm{C}$ & Transparent & - \\
Trombe wall & - & Not transparent & $800\left(\mathrm{w} / \mathrm{m}^{2}\right)$ \\
Front wall & $45^{\circ} \mathrm{C}$ & Not transparent & $250\left(\mathrm{w} / \mathrm{m}^{2} \mathrm{k}\right)$ \\
Other wall & Adiabatic & Not transparent & - \\
\hline
\end{tabular}

2.2. Mesh Independence Study and Boundary Conditions. The model of passive house with Trombe wall is a simple room with the Trombe wall on its south side and has a dimension of height $\times$ length $\times$ width of $3 \times 4 \times 4 \mathrm{~m}^{3}$. The Trombe wall is characterized by $0.3 \mathrm{~m}$ for the thickness, $0.3 \mathrm{~m}$ for air gap, and $2.4 \mathrm{~m}$ for height. The room is vacant and just heated by direct sunlight. The physical model of the system is exposed in Figure 1. The boundary condition details are summarized in Table 1.

The whole domain is modeled with a structured rectangular mesh in ANSYS, and the simulations were performed in CFX 15.0. The used turbulence model as discussed above was $k-\varepsilon$. It is assumed that a steady-state condition was executed. The independence of grid has been established. Six cases of meshes are tested, 62908, 112356, 132804, and 164388. From the velocity results showed in Figure 2, grid size and cell number independency happened after the mesh $\mathrm{N}^{\circ} 5$ and it has been shown that continuing the computation after this mesh $\left(\mathrm{N}^{\circ} 5\right.$ (cells 132804)) just prolonged the computation and it is performed only for accuracy purposes.

2.3. Climatic Data of the Town of Sousse. The town of Sousse $\left(35^{\circ} 49^{\prime} 34^{\prime \prime}\right.$ north, $10^{\circ} 38^{\prime} 24^{\prime \prime}$ east) is placed at $143 \mathrm{~km}$ from Tunis, at the south, and an altitude of $25 \mathrm{~m}$. In summer, the temperatures surpass $43^{\circ} \mathrm{C}$ in the shade, and the relative humidity is about $67 \%$. In addition, the outside temperature frequently differs between $10^{\circ} \mathrm{C}$ and $20^{\circ} \mathrm{C}$ in the winter at day time and can drop less than $1^{\circ} \mathrm{C}$ at night with inadequate and uneven rain.

\section{Results}

Many cases were studied in order to examine the heating/cooling potential of a Trombe wall system. In particular, we considered two different modes: the first is the coldest winter day in the year $(28 / 12 / 2019)$, and the second is a hot summer day in the same year (21/07/2019). Climatic conditions for Sousse (2019) are expressed in Table 2. The results are illustrated in a vertical plane at the center of the building. The results obtained are presented in figures with different values of the solar chimney depth in order to see the influence on the thermal efficiency of the system.

3.1. Validation of Computational Methods. To validate the mathematical model, the numerical results obtained by CFD are compared with the results of a traditional TW under the same conditions of the experimental studies [21]. The comparison of energy efficiencies of the Trombe walls for different solar radiation intensities was carried out between CFD results and experimental data and is shown in Figure 3. To evaluate the results, the relative error is used as an indicator. The RE between CFD and experimental results is calculated by

$$
\mathrm{RE}=\left|\frac{X_{\exp }-X_{\mathrm{CFD}}}{X_{\exp }}\right| \times 100
$$




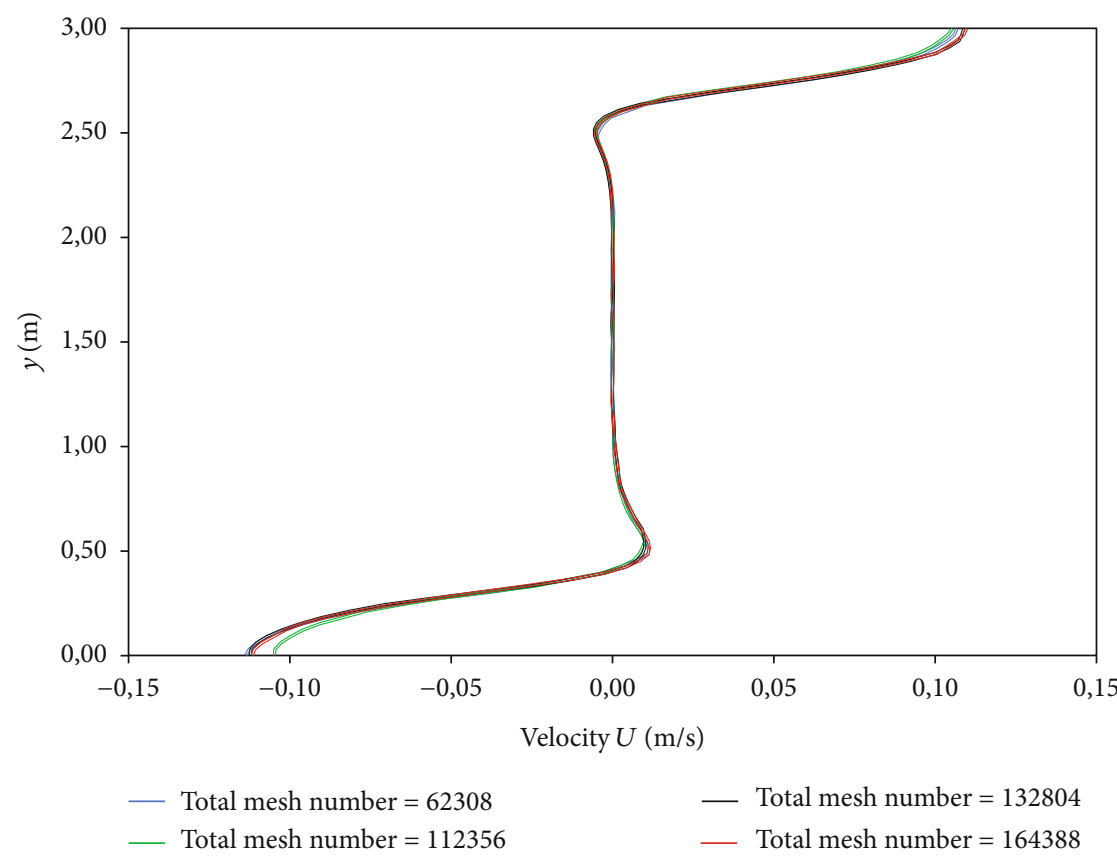

Figure 2: Model grid independency test.

TABLE 2: Climatic conditions for Sousse (2019).

\begin{tabular}{lccc}
\hline \multicolumn{2}{c}{ Sumer day } & $(21 / 07 / 2019)$ & \multicolumn{2}{c}{ Winter day } & $(28 / 12 / 209)$ \\
$T\left({ }^{\circ} \mathrm{C}\right)$ & $V(\mathrm{~m} / \mathrm{s})$ & $T\left({ }^{\circ} \mathrm{C}\right)$ & $V(\mathrm{~m} / \mathrm{s})$ \\
\hline 45 & 6.94 & 14.43 & 3.6 \\
\hline
\end{tabular}

As shown in Figure 3, a perfect agreement between the results obtained from the model and the published results is observed and the highest value of RE is $7.29 \%$.

3.2. Hot Summer Day. A typical hot day in summer (July) is selected, and simulation is performed under steady-state conditions. Figure 4 shows the temperature field in the room in the section located at $(Z=2 \mathrm{~m})$. Due to buoyancy, the cold air spreads at the floor level. This cold airflow is like a jet and persuades the surrounding air; the Trombe wall could reduce indoor air temperature on average of $6.1{ }^{\circ} \mathrm{C}$. In this case, the air temperature gradient between a horizontal plane at $0.2 \mathrm{~m}$ and the floor is $7^{\circ} \mathrm{C}$ which is very high, and this zone is warmer, and an overheating phenomenon in the room is also observed.

Figure 5 shows the raw velocity vector map after passing the glass cover; solar energy here has the first interaction with the system TW-FR. In the first hand, the solar energy is absorbed by the Trombe wall. As a result, by conduction, this energy is moved through the wall and the remaining is moved to the air in the channel by convection. The air moves from the bottom to the top of the channel caused by the chimney effect.

The highest air velocity is about $0.5 \mathrm{~m} / \mathrm{s}$. According to [22], we observed that the air velocity in the region occupied by the middle section of the domain is not exceeding $0.17 \mathrm{~m} / \mathrm{s}$ and this is between the comfort ranges. This condition that the average state air velocity is below $0.2 \mathrm{~m} / \mathrm{s}$ made the greatest situation for human comfort. According to [22], the velocities between 0.18 and $0.24 \mathrm{~m} / \mathrm{s}$ are perceivable but still in the comfort zone in summer.

3.3. Cold Winter Day. In this section, the simulations are prepared for a typical winter day at the month of January. Figure 6 shows the temperature field in the room at $(z=2 \mathrm{~m})$. Even though the radiation is very high at this day, it is sufficient to transfer the air in the channel. The average temperature for the central point of the room is $18.46^{\circ} \mathrm{C}$. The higher temperature in the room is around $20^{\circ} \mathrm{C}$, and the minimum is about $10^{\circ} \mathrm{C}$. The internal temperature offered higher values than external temperature getting the difference of $6.45^{\circ} \mathrm{C}$. It can be concluded from the simulations that the temperature inside reached higher temperature compared to outside in a large zone of the system which is a negative result and will drive the heat flux from inside of the room to ambient. This can see obviously the high temperatures near the wall.

Figure 7 shows that the maximum velocities are positioned near the roof and floor. This flow causes a temperature gradient between regions. A small vortex is produced at the corner close to the room outlet. Reverse flow patterns were strong near floor. A relatively small recirculation zone was created, and a flow was observed. We observed also that the air flow is characterized by a strong turbulence near the floor and roof. High air velocities existed; the highest velocity is about $0.34 \mathrm{~m} / \mathrm{s}$. The air velocity in the region where it is thought that will be occupied (the mid region of the domain) 


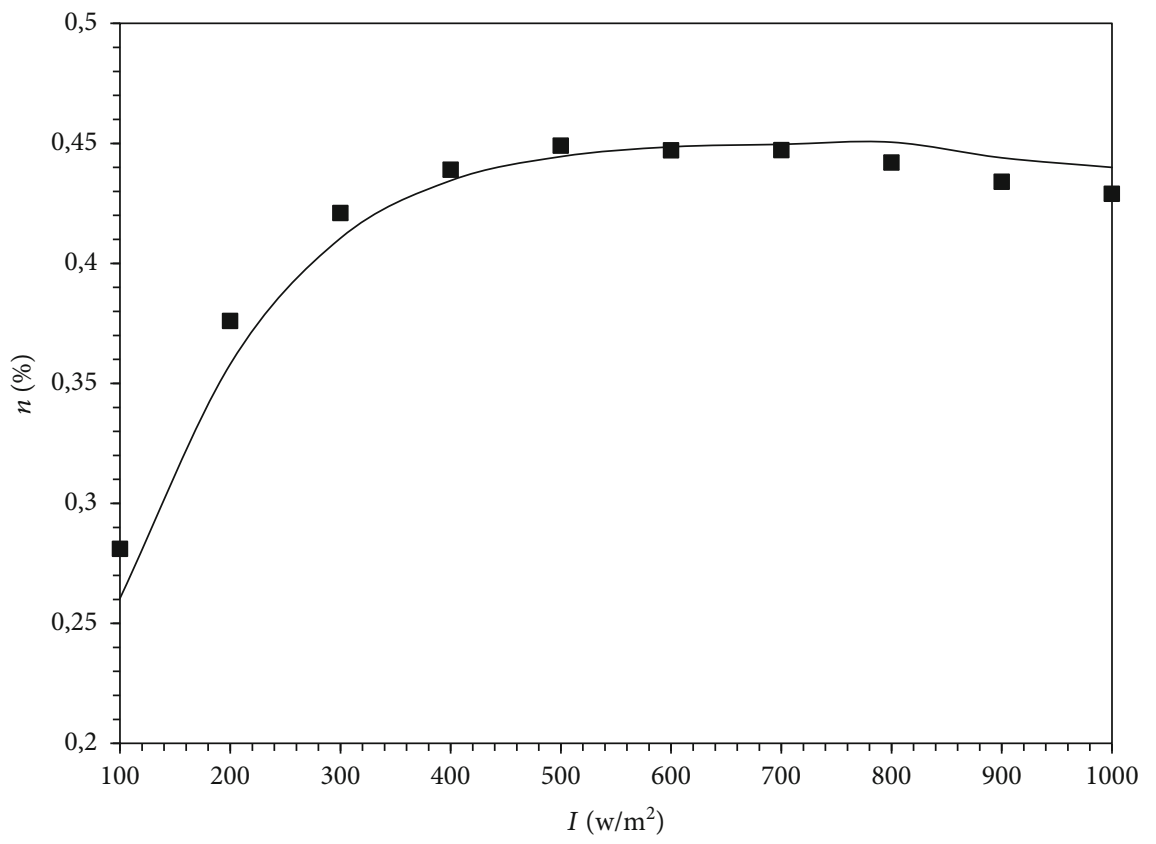

Exp.Data

- CFD

Figure 3: Comparison of thermal efficiency.

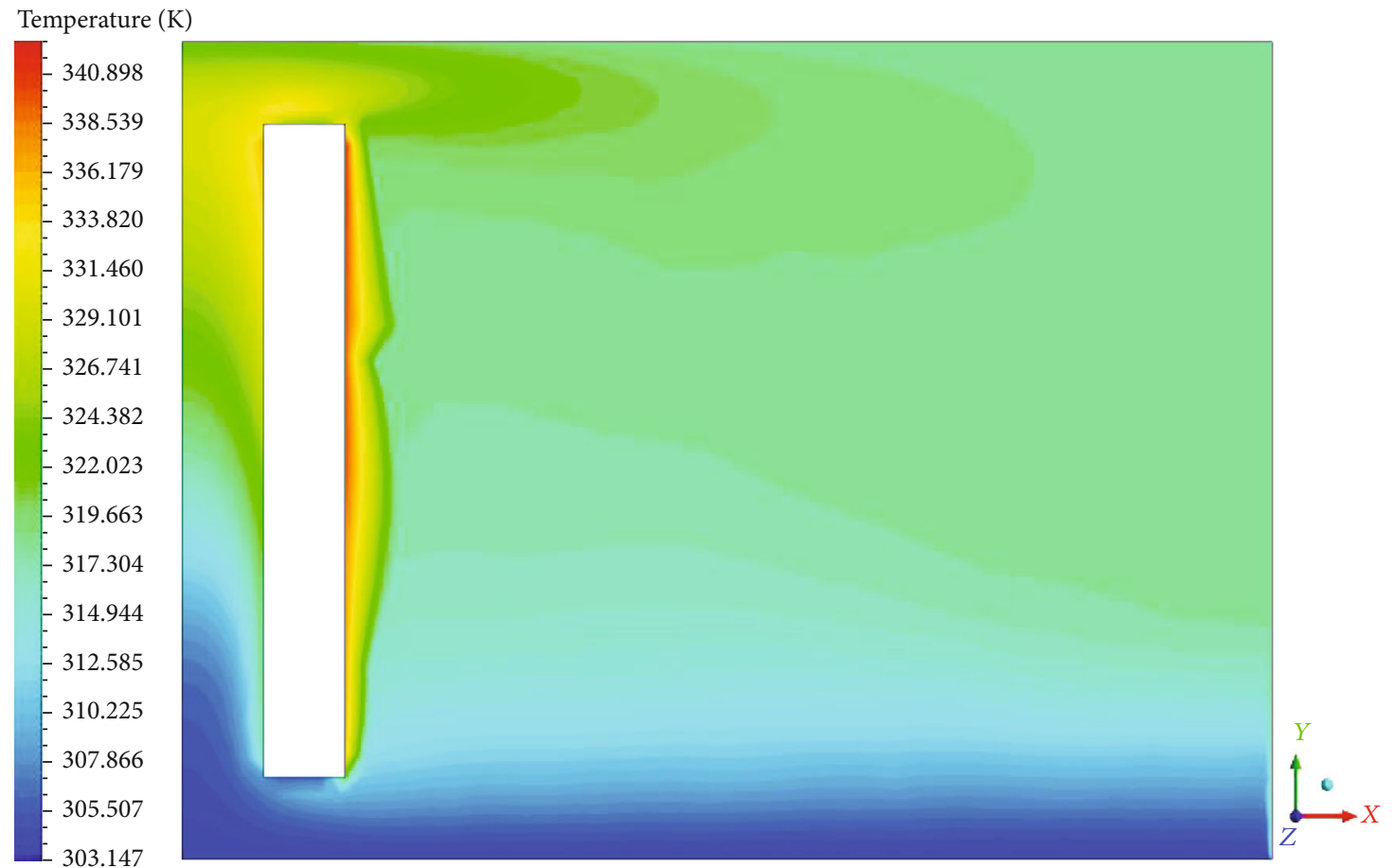

FIgURE 4: Temperature contour on plane $z=2 \mathrm{~m}$ in the case of summer hot day. 


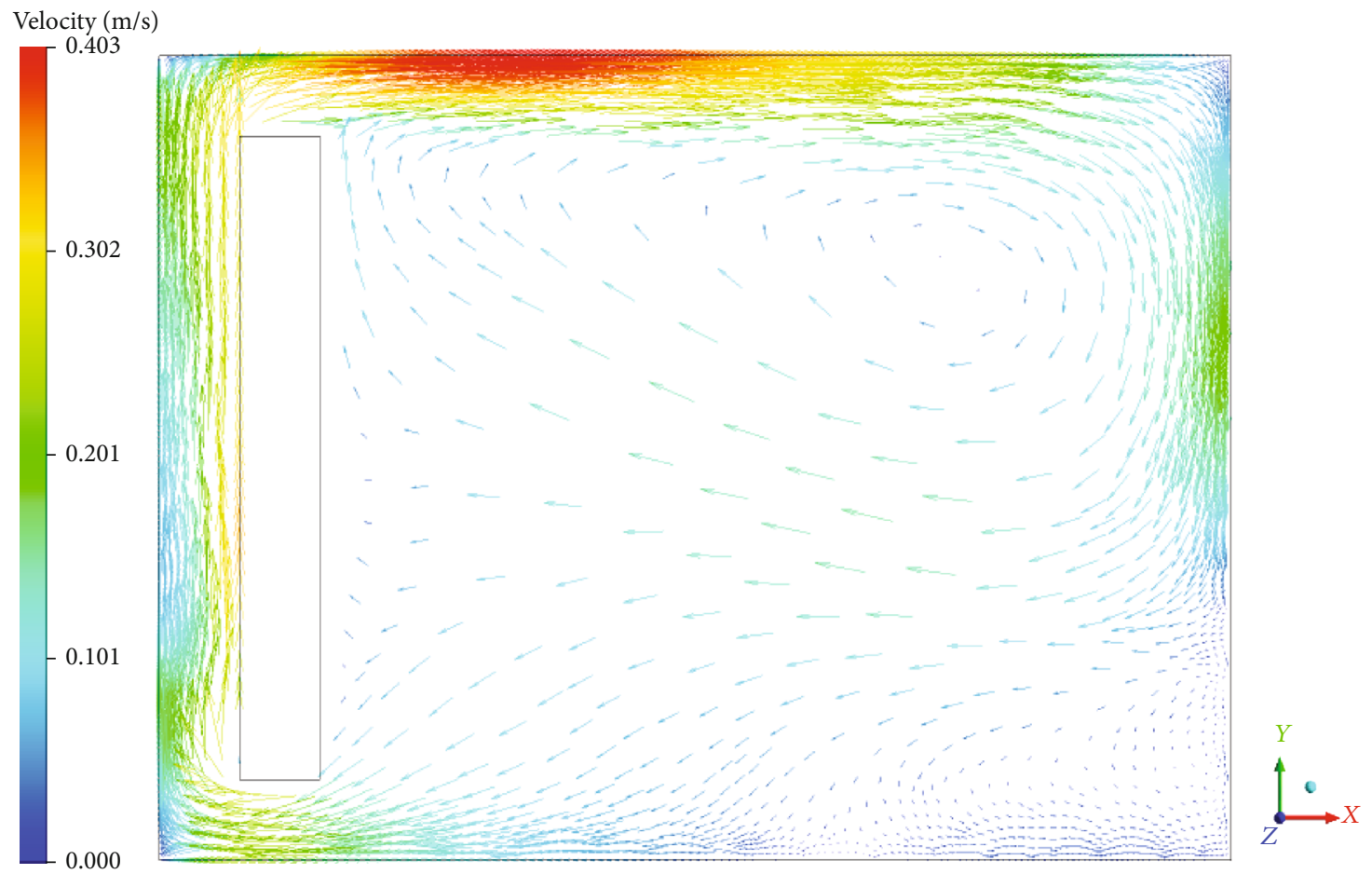

Figure 5: Vector velocity on plane $z=2 \mathrm{~m}$ in the case of summer hot day.

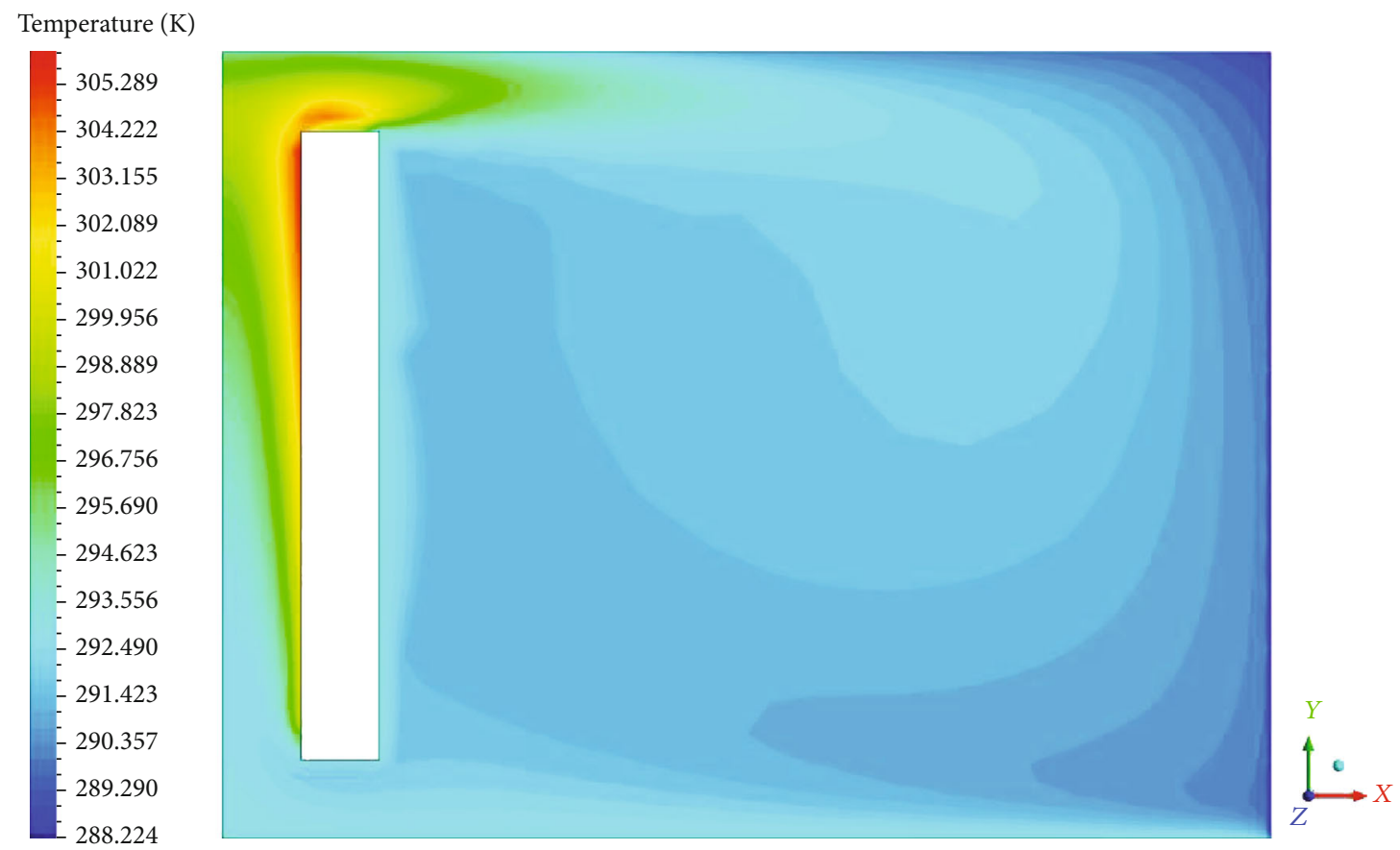

Figure 6: Temperature contour on plane $z=2 \mathrm{~m}$ in the case of the winter coldest day.

is not exceeding $0.21 \mathrm{~m} / \mathrm{s}$. According to [22], this result is between the comfort zones.

The numerical distribution of pressure (Figures 8 and 9) is completely hydrostatic and also slightly small compared to atmospheric pressure particularly in the lower part of the Trombe wall due to the loss at the inlet restriction. A slight difference in distribution of pressure is appreciated between the air gap and the room, mainly in areas of low inlet and outlet pressure of Trombe wall.

The turbulent kinetic energy is discussed in Figures 10 and 11. At the input side, viscosity degraded the turbulent kinetic energy. Since there is no speed gradient nor $k$ 

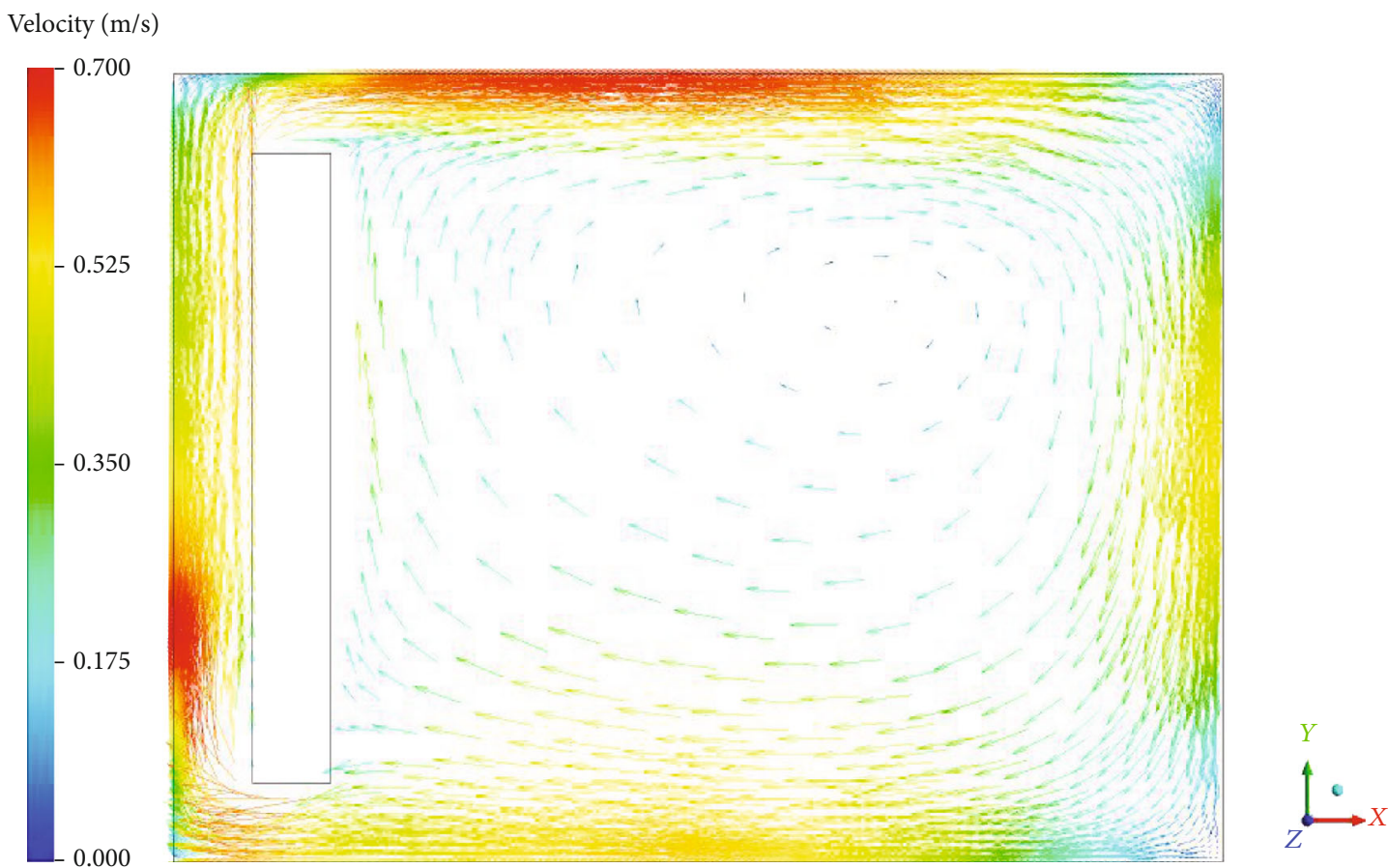

Figure 7: Vector velocity on plane $\mathrm{z}=2 \mathrm{~m}$ in the case of the winter coldest day.

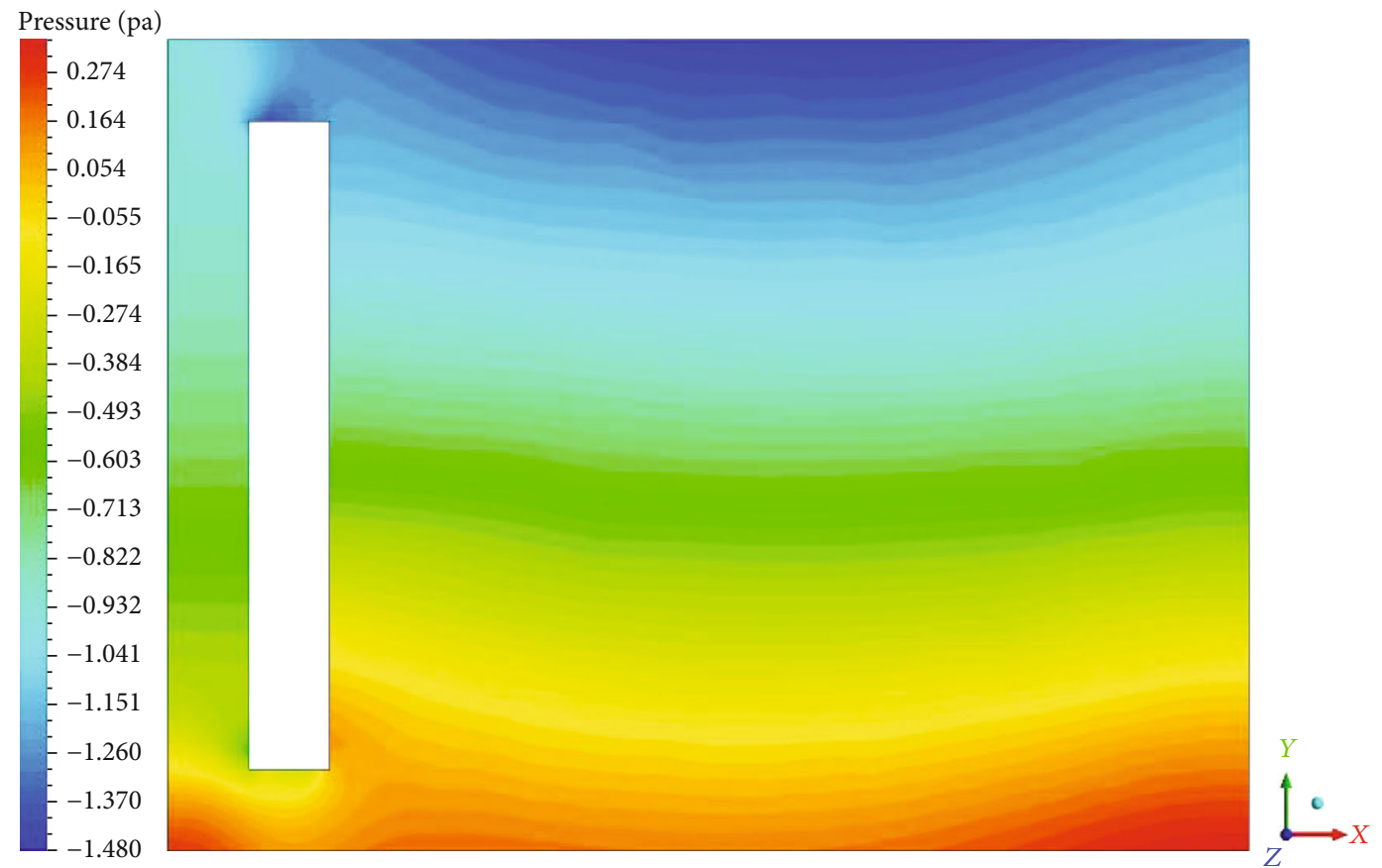

Figure 8: Pressure map in the plane $z=2 \mathrm{~m}$ in the case of the winter coldest day.

gradient, a balance is achieved between the convection heat transfer and dissipation rate in the transport equation.

\section{Discussion}

The most cited technique in the literature to explain the indoor thermal comfort in buildings is according to Fanger's comfort model [23], which is also used in [22, 24]. Where the thermal comfort is frequently examined inside the occupied zone, the volume occupants normally use is the volume enclosed by two horizontal planes, one $0.1 \mathrm{~m}$ above floor level and the other $2.0 \mathrm{~m}$ above floor level. The local discomfort can be classified generally as per the following according to the current standards and ASHRAE Fundamentals Handbook. 


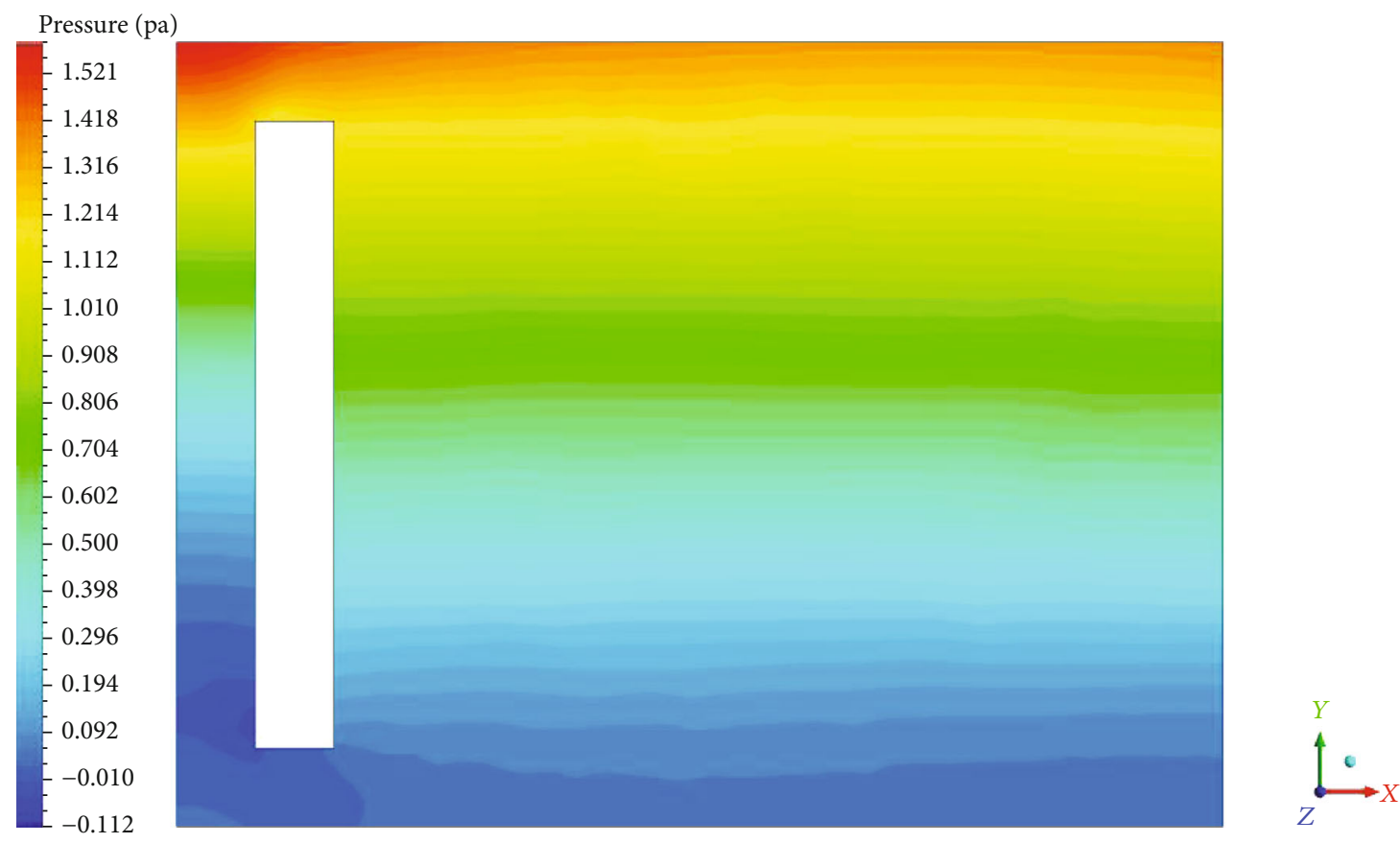

FIgURE 9: Pressure map in the plane $z=2 \mathrm{~m}$ in the case of summer hot day.

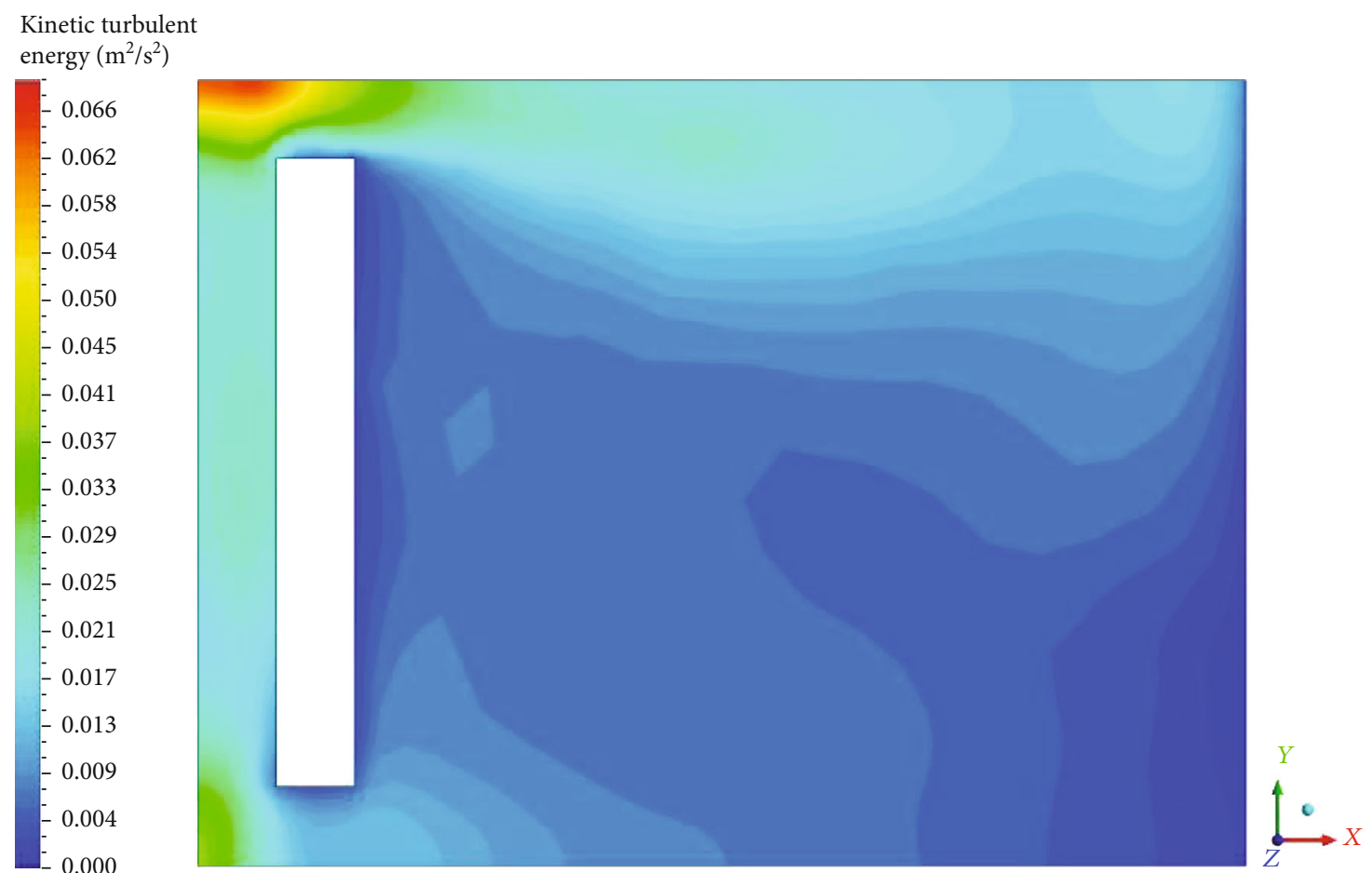

FIgURE 10: Turbulent kinetic energy in the case of summer hot day.

4.1. Operative Temperature. It can be defined by the uniform temperature of a pretend black enclosure in which a person would exchange the same amount of heat by radiation and convection as in an actual nonuniform environment. It is calculated according to

$$
\begin{gathered}
T_{\text {op }}=\frac{T_{\mathrm{r}}+T_{\mathrm{a}} \sqrt{10 v}}{1+\sqrt{10 v}} \text { if } v>10 \mathrm{~m} / \mathrm{s}, \\
T_{\text {op }}=\frac{T_{\mathrm{r}}+T_{\mathrm{a}}}{2} \text { if } v \leq 0.1 \mathrm{~m} / \mathrm{s},
\end{gathered}
$$



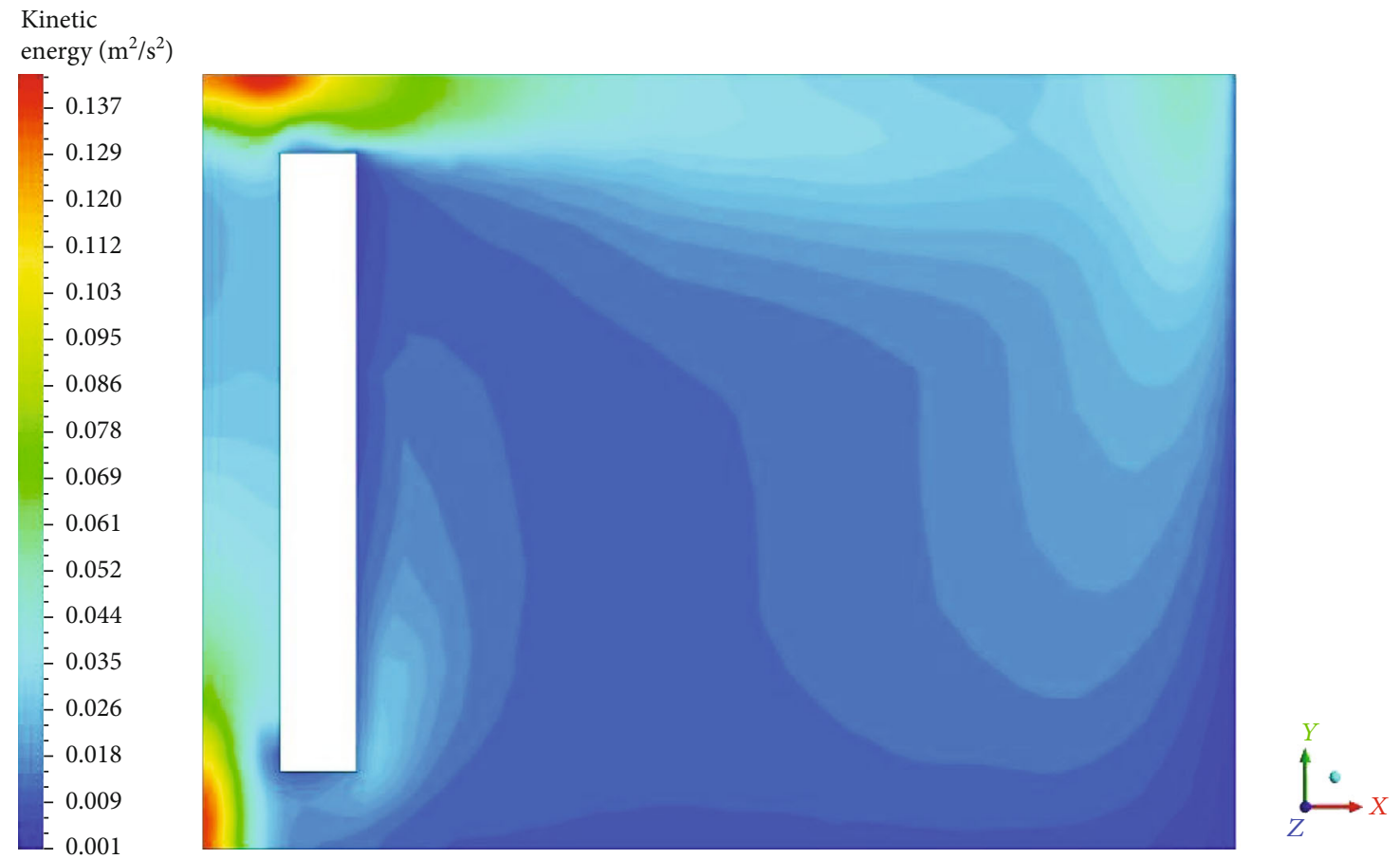

FIGURE 11: Turbulent kinetic energy in the case of winter coldest day.

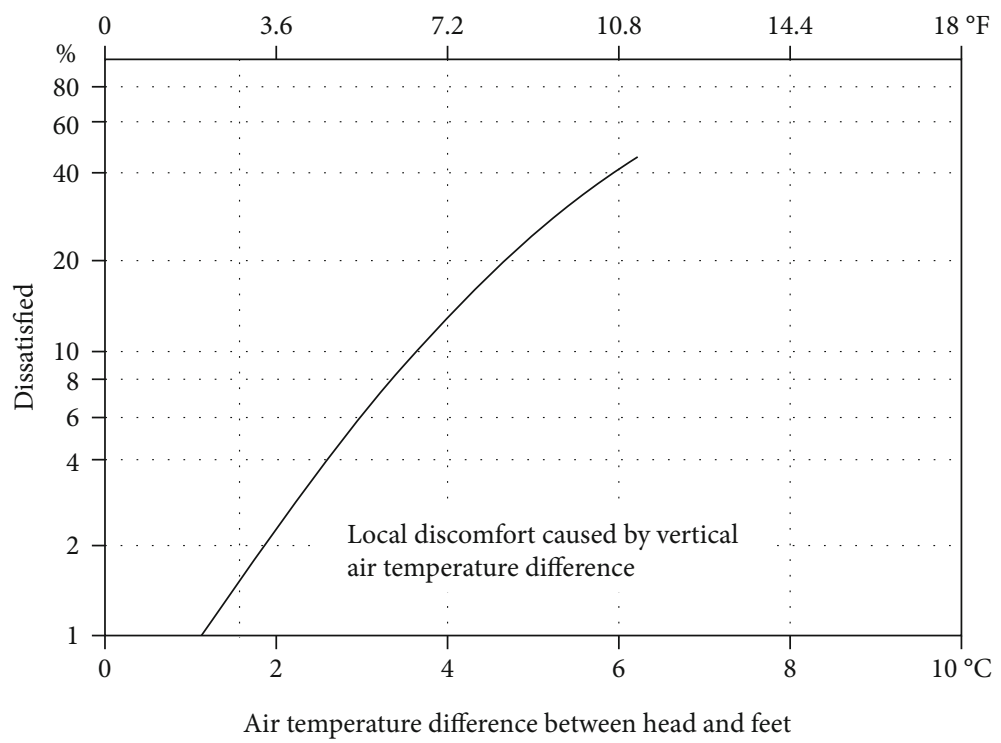

FIGURE 12: Local thermal discomfort caused by vertical temperature differences [22].

where $T_{\mathrm{a}}$ is the ambient air temperature, $T_{\mathrm{r}}$ the radiation temperature, and $v$ the air velocity.

4.2. Vertical Air Temperature Difference. Thermal discomfort may happen as a result of thermal stratification. Figure 12 demonstrates the estimated value of dissatisfied people with respect to air temperature gradient where the ankle level is colder than the head level.

The thermal comfort for room equipped with a Trombe wall was considered under the coldest winter day and the hot summer day. The main parameter shown in the figures was the operative temperature. The hot summer day gave a bad thermal comfort, and the temperature difference over the entire room is small. The operative temperatures were around $29-44^{\circ} \mathrm{C}$ in the horizontal plane (Figure 13). The numerical results also show higher vertical temperature gradients which can take a value of $15^{\circ} \mathrm{C}$ (Figure 14); the results show also that operative temperature in the room is not within the comfort range. This demonstrates that the normal Trombe wall cannot assure a satisfactory comfort level even 


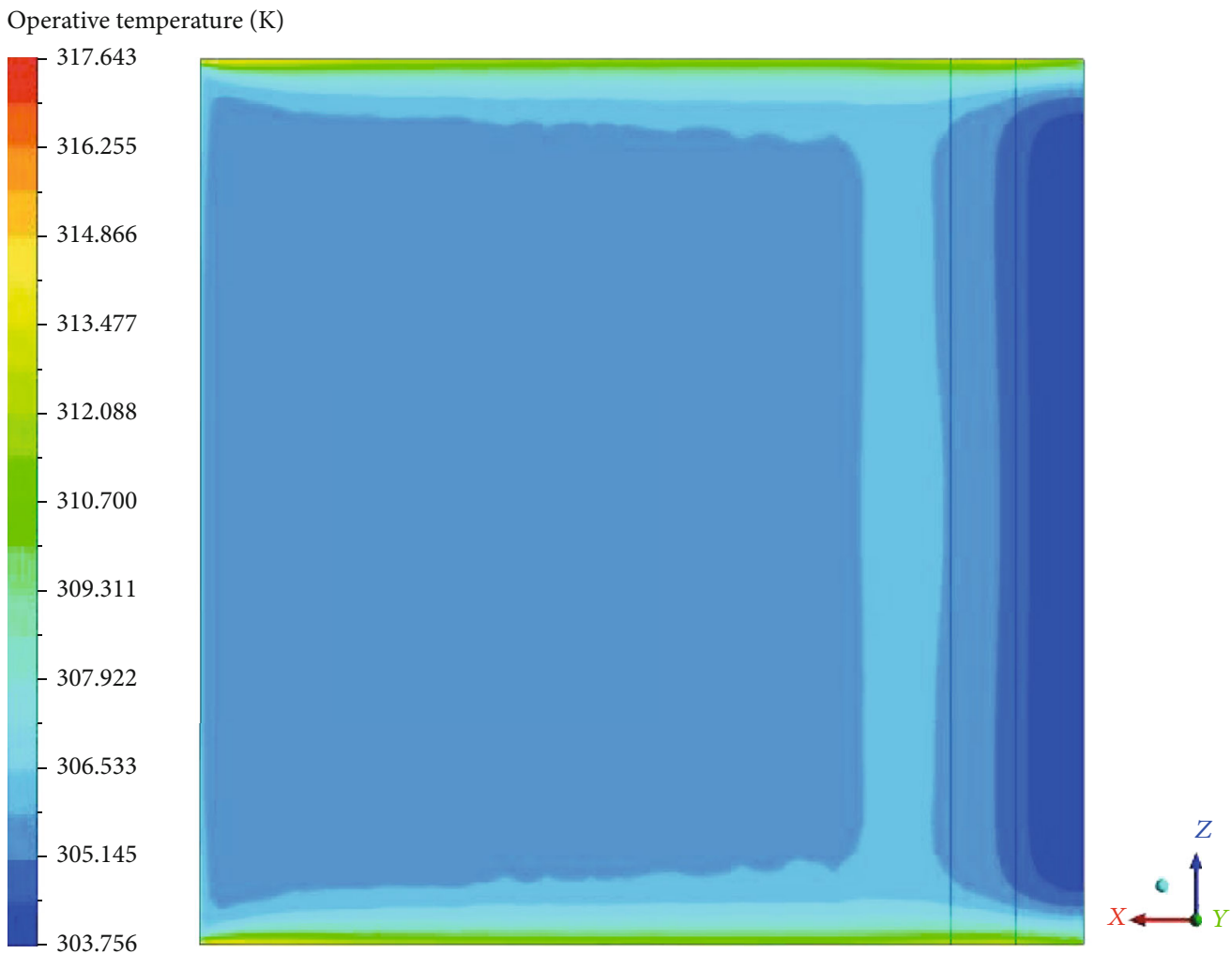

Figure 13: Operative temperature distribution at $0.1 \mathrm{~m}$ above the floor in a summer day.

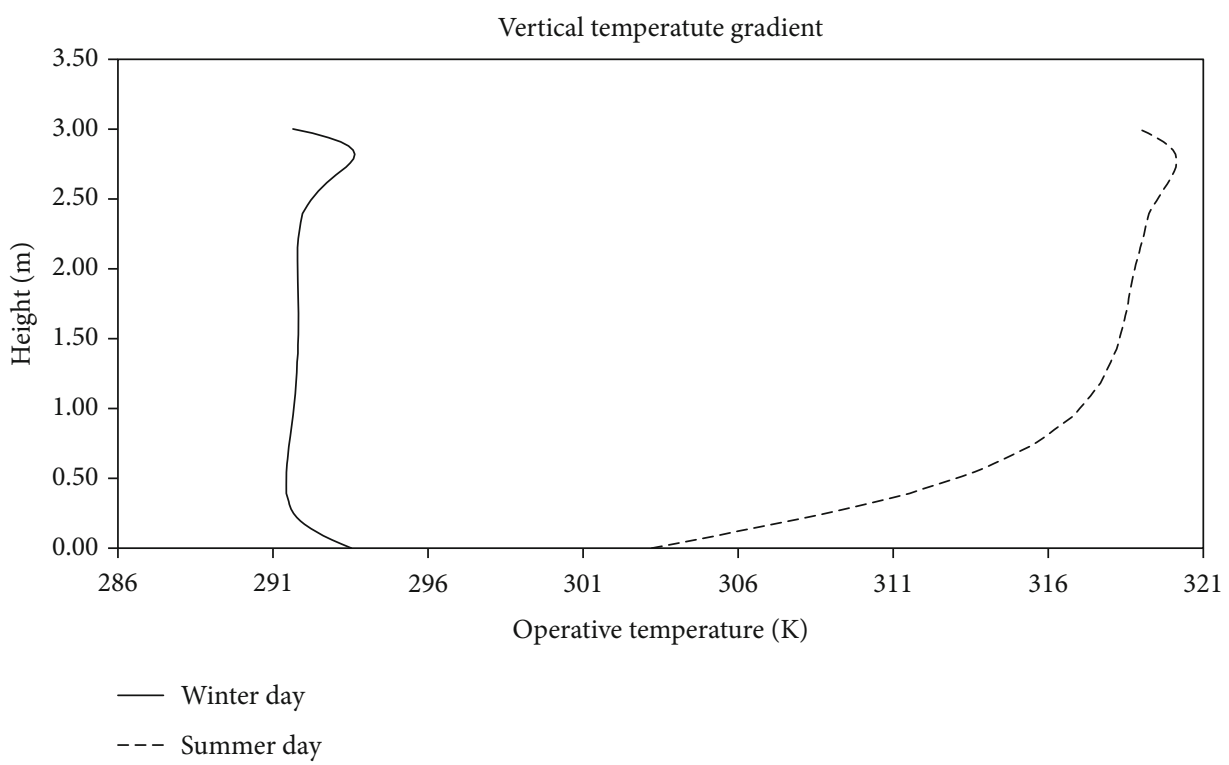

FIgURE 14: Vertical operative temperature gradient at the line ( $x=2 \mathrm{~m}$ and $z=2 \mathrm{~m})$.

in summer conditions. In this case, the air temperature gradient between head level and ankle level is $10^{\circ} \mathrm{C}$ which exceeds $3^{\circ} \mathrm{C}$ and the discomfort is sensed because the head level is warmer than the ankle level according to [22]. As a result, the typical Trombe wall cannot reduce the effect of heating in the summer season. Consequently, heating seasons in
Tunisia should introduce some modification in the Trombe wall like the use of a water tank, which is part of the building's wall or it must ventilate the room with air circulation open.

This case of the coldest winter day (Figure 15) shows the most irregular distribution, and the vertical temperature gradients in the occupied zone are fewer than $2.5^{\circ}$. The operative 


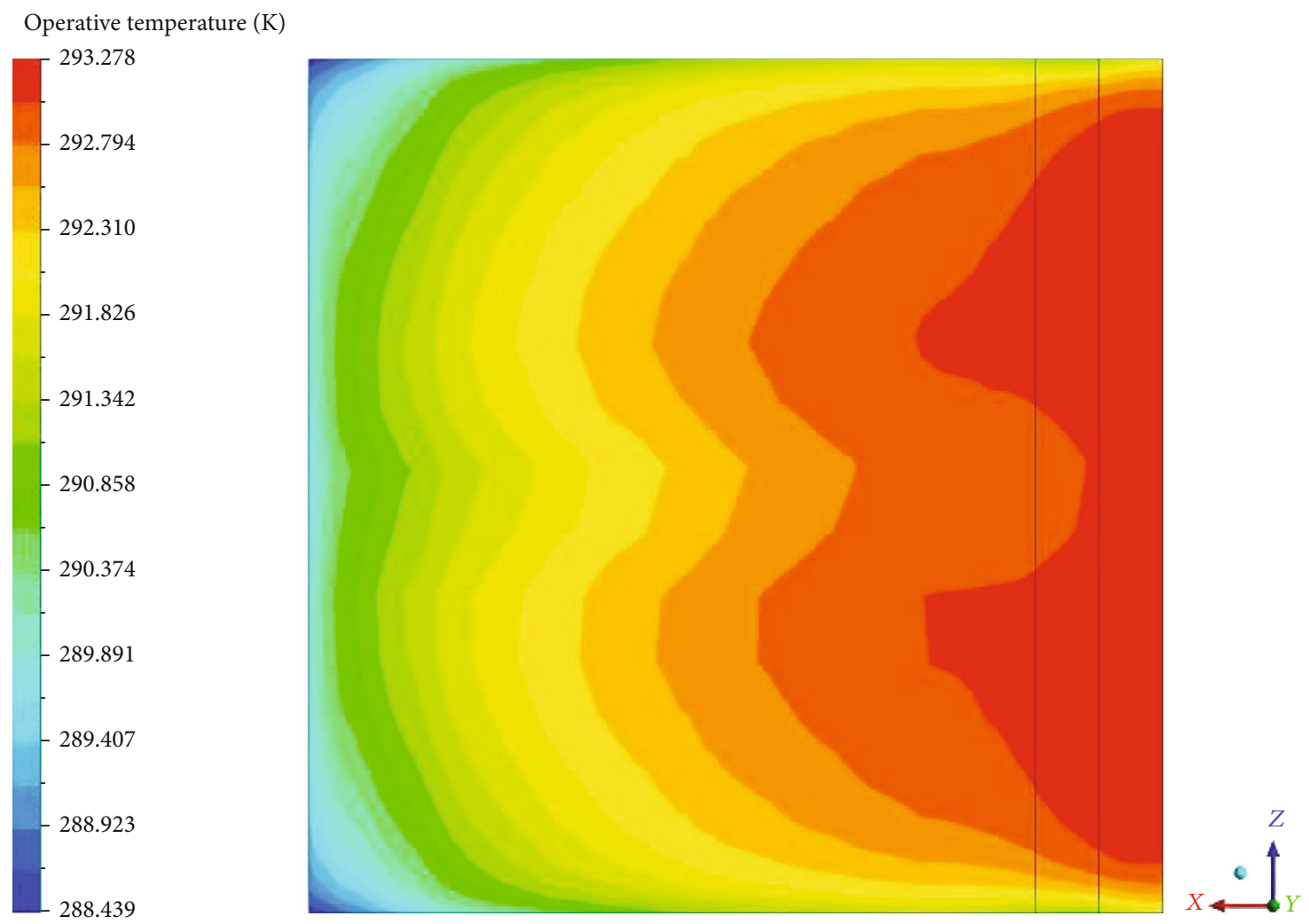

FIGURE 15: Operative temperature distribution at $0.1 \mathrm{~m}$ above the floor in winter.

temperature for the coldest winter is between 17.85 and $19.85^{\circ} \mathrm{C}$. The air temperature gradient between the head and feet is $2.3^{\circ} \mathrm{C}$. Based on [22], this is between the comfort ranges and $5 \%$ of occupants are dissatisfied by the vertical air stratification.

\section{Conclusion(s)}

The following remarks can be concluded from this study:

(i) The CFD simulation is able to provide accurate air temperature and velocity distributions inside the building room

(ii) It was observed from the simulations that installing the Trombe wall can highly influence the temperature distribution inside the modeled house for Sousse city weather information

(iii) It was shown that installing the Trombe wall had significant influence on the temperature of the room that it was kept around $20^{\circ} \mathrm{C}$ in winter conditions

(iv) However, in summer conditions, a normal Trombe wall can be considered an additional source of heating for the building

(v) The typical Trombe wall cannot reduce the effect of heating in the summer season. Consequently, during hot seasons in Tunisia, some modifications in the Trombe wall should be introduced

\section{Nomenclature}

\begin{tabular}{|c|c|}
\hline$t:$ & Time (s) \\
\hline$k$ : & Turbulent kinetic energy $\left(\mathrm{m}^{2} / \mathrm{s}^{2}\right)$ \\
\hline$l:$ & Turbulent mixing length (m) \\
\hline$i, j:$ & Cartesian coordinate index \\
\hline$C_{\mathrm{a}}:$ & Constant pressure specific heat $(\mathrm{J} / \mathrm{kgK})$ \\
\hline$T:$ & Temperature $(\mathrm{K})$ \\
\hline$K:$ & Thermal conductivity $(\mathrm{w} / \mathrm{mK})$ \\
\hline$g:$ & Gravity acceleration (m/s²) \\
\hline$F:$ & Body force $\left(\mathrm{N} / \mathrm{m}^{3}\right)$ \\
\hline CFD: & Computational fluid dynamics \\
\hline$C_{1 \varepsilon}, C_{2 \varepsilon}:$ & Constants \\
\hline$C_{3 \varepsilon}, C_{\mu}:$ & Constants \\
\hline$G_{\mathrm{b}}:$ & Buoyancy kinetic energy $\left(\mathrm{kg} / \mathrm{m} \mathrm{s}^{3}\right)$ \\
\hline$G_{k}:$ & $\begin{array}{l}\text { Velocity gradients turbulent kinetic energy } \\
\left(\mathrm{kg} / \mathrm{ms}^{3}\right)\end{array}$ \\
\hline$\mu_{\mathrm{t}}:$ & Effective viscosity $\left(\mathrm{m}^{2} / \mathrm{s}\right)$ \\
\hline$Y_{\mathrm{M}}:$ & $\begin{array}{l}\text { Contribution of the fluctuating dilatation in com- } \\
\text { pressible turbulence to the overall dissipation rate } \\
\left(\mathrm{kg} / \mathrm{m} \mathrm{s}^{2}\right)\end{array}$ \\
\hline$S_{k}, S_{\varepsilon}:$ & Mass source $\left(\mathrm{kg} / \mathrm{m}^{3}\right)$ \\
\hline$C_{\mathrm{p}}:$ & Specific heat (J/kgK) \\
\hline$L:$ & Characteristic length (m) \\
\hline Pr: & Prandtl number \\
\hline
\end{tabular}


Gr: $\quad$ Grashof number

$T_{\mathrm{r}}$ : $\quad$ Radiation temperature $(\mathrm{K})$

$T_{\mathrm{a}}$ : $\quad$ Ambient temperature $(\mathrm{K})$.

\section{Greek Symbols}

$\sigma_{k}, \sigma_{\varepsilon}:$ Turbulent Prandtl

$v: \quad$ Kinematic viscosity $\left(\mathrm{m}^{2} / \mathrm{s}\right)$

$\alpha: \quad$ Thermal diffusivity $\left(\mathrm{m}^{2} / \mathrm{s}\right)$

$\beta$ : $\quad$ Thermal expansion coefficient $\left(\mathrm{K}^{-1}\right)$

$\varepsilon: \quad$ Turbulent dissipation rate $\left(\mathrm{m}^{2} / \mathrm{s}^{3}\right)$

$k$ : Turbulent kinetic energy $\left(\mathrm{m}^{2} / \mathrm{s}^{2}\right)$

$\delta_{i j}: \quad$ Kronecker delta.

\section{Data Availability}

Data are available on request.

\section{Conflicts of Interest}

The authors declare that they have no conflicts of interest.

\section{References}

[1] M. el Haj Assad, M. H. Ahmadi, M. Sadeghzadeh, A. Yassin, and A. Issakhov, "Renewable hybrid energy systems using geothermal energy: hybrid solar thermal-geothermal power plant," International Journal of Low-Carbon Technologies, 2020.

[2] M. Ghazvini, M. Sadeghzadeh, M. H. Ahmadi, S. Moosavi, and F. Pourfayaz, "Geothermal energy use in hydrogen production: a review," International Journal of Energy Research, vol. 14, pp. 7823-7851, 2019.

[3] M. H. Ahmadi, M. Ghazvini, M. Sadeghzadeh et al., "Solar power technology for electricity generation: a critical review," Energy Science \& Engineering, vol. 6, no. 5, pp. 340-361, 2018.

[4] M. Sadeghzadeh, M. H. Ahmadi, M. Kahani, H. Sakhaeinia, H. Chaji, and L. Chen, "Smart modeling by using artificial intelligent techniques on thermal performance of flat-plate solar collector using nanofluid," Energy Science \& Engineering, vol. 7, no. 5, pp. 1649-1658, 2019.

[5] A. B. Baci, M. Salmi, Y. Menni, S. Ghafourian, M. Sadeghzadeh, and M. Ghalandari, "A new configuration of vertically connecting solar cells: solar tree," International Journal of Photoenergy, vol. 2020, 8 pages, 2020.

[6] M. H. Ahmadi, A. Baghban, M. Sadeghzadeh et al., "Evaluation of electrical efficiency of photovoltaic thermal solar collector," Engineering Applications of Computational Fluid Mechanics, vol. 14, no. 1, pp. 545-565, 2020.

[7] M. H. Ahmadi, M. Dehghani Madvar, M. Sadeghzadeh, M. H. Rezaei, M. Herrera, and S. Shamshirband, "Current status investigation and predicting carbon dioxide emission in Latin American countries by connectionist models," Energies, vol. 12, no. 10, p. 1916, 2019.

[8] M. H. Rezaei, M. Sadeghzadeh, M. Alhuyi Nazari, M. H. Ahmadi, and F. R. Astaraei, "Applying GMDH artificial neural network in modeling CO2 emissions in four nordic countries," International Journal of Low-Carbon Technologies, vol. 13, no. 3, pp. 266-271, 2018.

[9] M. Hordesiki, Dictionary of Energy Efficiency Technologies, The Fairmont Press, Inc., 1st ed edition, 2004.
[10] G. Gan, "A parametric study of Trombe walls for passive cooling of buildings," Energy and Buildings, vol. 27, no. 1, pp. 37-43, 1998.

[11] M. Rabani and M. Rabani, "Heating performance enhancement of a new design Trombe wall using rectangular thermal fin arrays: an experimental approach," Journal of Energy Storage, vol. 24, p. 100796, 2019.

[12] J. Dong, Z. Chen, L. Zhang, Y. Cheng, S. Sun, and J. Jie, "Experimental investigation on the heating performance of a novel designed Trombe wall," Energy, vol. 168, pp. 728-736, 2019.

[13] F. Abbassi and L. Dehmani, "Experimental and numerical study on thermal performance of an unvented Trombe wall associated with internal thermal fins," Energy and Buildings, vol. 105, pp. 119-128, 2015.

[14] S.-Y. Wu, L. Xu, and L. Xiao, "Air purification and thermal performance of photocatalytic-Trombe wall based on multiple physical fields coupling," Renewable Energy, vol. 148, pp. 338348, 2020.

[15] A. Abdeen, A. A. Serageldin, M. G. E. Ibrahim, A. El-Zafarany, S. Ookawara, and R. Murata, "Experimental, analytical, and numerical investigation into the feasibility of integrating a passive Trombe wall into a single room," Applied Thermal Engineering, vol. 154, pp. 751-768, 2019.

[16] M. Dhahri and H. Aouinet, "CFD investigation of temperature distribution, air flow pattern and thermal comfort in natural ventilation of building using solar chimney," World Journal of Engineering, vol. 17, no. 1, pp. 78-86, 2020.

[17] D. Risberg, M. Risberg, and L. Westerlund, "Investigation of thermal indoor climate for a passive house in a sub-Arctic region using computational fluid dynamics," Indoor and Built Environment, vol. 28, no. 5, pp. 677-692, 2019.

[18] T. Bajc, M. N. Todorović, and J. Svorcan, "CFD analyses for passive house with Trombe wall and impact to energy demand," Energy and Buildings, vol. 98, pp. 39-44, 2015.

[19] M. Dhahri and H. Aouinet, "Hydrodynamics in two-phase turbulent boundary layers," Journal of Applied Fluid Mechanics, vol. 11, no. 1, pp. 55-63, 2018.

[20] D. Maher, A. Hana, and H. Sammouda, "Numerical approximation of air flow, temperature distribution and thermal comfort in buildings," Scientific African, vol. 8, article e00353, 2020.

[21] S. Duan, C. Jing, and Z. Zhao, "Energy and exergy analysis of different Trombe walls," Energy and Buildings, vol. 126, pp. 517-523, 2016.

[22] American Society of Heating, Refrigerating, Air-Conditioning Engineers, and American National Standards Institute, Thermal Environmental Conditions for Human Occupancy, vol. 55, American Society of Heating, Refrigerating and Air-Conditioning Engineers, 2004.

[23] P. O. Fanger, Thermal comfort. Analysis and applications in environmental engineering, Danish Technical Press, Copenhagen, 1970.

[24] P. Lenzuni, D. Freda, and M. del Gaudio, "Classification of thermal environments for comfort assessment," The Annals of Occupational Hygiene, vol. 53, no. 4, pp. 325-332, 2009. 